\title{
Seal Occurrence and Habitat Use during Summer in Petermann Fjord, Northwestern Greenland
}

\author{
Kate Lomac-MacNair, ${ }^{1,2}$ Martin Jakobsson, ${ }^{3}$ Alan Mix, ${ }^{4}$ Francis Freire, ${ }^{3}$ Kelly Hogan, ${ }^{5}$ Larry Mayer ${ }^{6}$ \\ and Mari A. Smultea ${ }^{2}$
}

(Received 29 June 2017; accepted in revised form 30 May 2018)

\begin{abstract}
Ice-associated seals are considered especially susceptible and are potentially the first to modify distribution and habitat use in response to physical changes associated with the changing climate. Petermann Glacier, part of a unique ice-tongue fjord environment in a rarely studied region of northwestern Greenland, lost substantial sections of its ice tongue during major 2010 and 2012 calving events. As a result, changes in seal habitat may have occurred. Seal occurrence and distribution data were collected in Petermann Fjord and adjacent Nares Strait region over 27 days (2 to 28 August) during the multidisciplinary scientific Petermann 2015 Expedition on the icebreaker Oden. During 239.4 hours of dedicated observation effort, a total of 312 individuals were recorded, representing four species: bearded seal (Erignathus barbatus), hooded seal (Crystophora cristata), harp seal (Pagophilus groenlandicus), and ringed seal (Pusa hispida). Ringed seals were recorded significantly more than the other species $\left(\chi^{2}=347.4, \mathrm{df}=3, p<0.001, \mathrm{n}=307\right)$. We found significant differences between species in haul-out (resting on ice) behavior $\left(\chi^{2}=133.1, \mathrm{df}=3, p<0.001, \mathrm{n}=307\right)$. Bearded seals were more frequently hauled out $(73.1 \% \mathrm{n}=49)$, whereas ringed seals were almost exclusively in water $(93.9 \%, \mathrm{n}=200)$. Differences in average depth and ice coverage where species occurred were also significant: harp seals and bearded seals were found in deeper water and areas of greater ice coverage (harp seals: $663 \pm 366 \mathrm{~m}$ and $65 \pm 14 \%$ ice cover; bearded seals: $598 \pm 259 \mathrm{~m}$ and $50 \pm 21 \%$ ice cover), while hooded seals and ringed seals were found in shallower water with lower ice coverage (hooded seals: $490 \pm 163 \mathrm{~m}$ and $38 \pm 19 \%$ ice cover; ringed seals: $496 \pm 235 \mathrm{~m}$, and $21 \pm 20 \%$ ice cover). Our study provides an initial look at how High Arctic seals use the rapidly changing Petermann Fjord and how physical variables influence their distribution in one of the few remaining ice-tongue fjord environments.
\end{abstract}

Key words: Petermann Glacier; marine mammals; ice-tongue fjord; Arctic seals; sea ice; Pusa hispida; Erignathus barbatus; Crystophora cristata; Pagophilus groenlandicus

RÉSUMÉ. Les phoques associés aux glaces sont considérés comme très susceptibles et sont potentiellement les premiers à modifier la répartition de leur population et la façon dont ils utilisent leur habitat en réponse aux changements physiques découlant des changements climatiques. Le glacier Petermann fait partie d'une langue glaciaire de fjord unique dans une région rarement étudiée du nord-ouest du Groenland. De gros blocs de glace se sont détachés du glacier Petermann pendant le vêlage de 2010 à 2012. Par conséquent, l'habitat des phoques aurait pu être modifié. Pendant 27 jours (du 2 au 28 août), des données sur la présence et la répartition des phoques ont été recueillies au fjord Petermann et dans la région adjacente du détroit de Nares dans le cadre de l'expédition scientifique multidisciplinaire Petermann 2015 sur le brise-glace Oden. Au cours de 239,4 heures d'observation soutenue, la présence d'un total de 312 phoques représentant quatre espèces a été notée : le phoque barbu (Erignathus barbatus), le phoque à capuchon (Crystophora cristata), le phoque du Groenland (Pagophilus groenlandicus) et le phoque annelé (Pusa hispida). La présence de phoques annelés est considérablement plus importante que celle des autres espèces $\left(\chi^{2}=347,4, \mathrm{ddl}=3, p<0,001, \mathrm{n}=307\right)$. Nous avons constaté une différence significative dans les comportements d'échouerie (repos sur la glace) des phoques selon les espèces $\left(\chi^{2}=133,11\right.$, ddl $=3, p<0,001, \mathrm{n}=307$ ). Les phoques barbus étaient plus souvent hors de l'eau $(73,1 \%, \mathrm{n}=49)$, tandis que les phoques annelés se trouvaient presque exclusivement dans l'eau $(93,9 \%, \mathrm{n}=200)$. Des différences significatives en ce qui a trait à la présence des espèces selon la profondeur et la couverture glaciaire ont été notées. Les phoques du Groenland et les phoques barbus fréquentent les profondeurs d'eau moyennes ( $663 \pm 366 \mathrm{~m}$ et $598 \pm 259 \mathrm{~m}$, respectivement) et les régions où la couverture de glace correspond à la moyenne supérieure (65 $\pm 14 \%$ et $50 \pm 21 \%$, respectivement), tandis que les phoques à capuchon et les phoques annelés

\footnotetext{
${ }^{1}$ Corresponding author: Center of Marine Sciences (CCMAR) University of Algarve, Gambelas Campus, 8005-139 Faro, Portugal; klomacmacnair@gmail.com

2 Smultea Sciences, PO Box 256 Preston, Washington 98050, USA

${ }^{3}$ Department of Geological Sciences, Stockholm University, SE-106 91, Stockholm, Sweden

${ }^{4}$ College of Oceanic and Atmospheric Sciences, Oregon State University, Corvallis, Oregon 97331, USA

${ }^{5}$ British Antarctic Survey, Natural Environment Research Council, High Cross, Madingley Road, Cambridge CB3 0ET, United Kingdom

${ }^{6}$ Center for Coastal and Ocean Mapping, Joint Hydrographic Center, University of New Hampshire, Durham, New Hampshire 03824, USA

(C) The Arctic Institute of North America
} 
fréquentent les eaux moins profondes ( $490 \pm 163 \mathrm{~m}$ et $496 \pm 235 \mathrm{~m}$, respectivement) et les régions où la couverture de glace correspond à la moyenne inférieure $(38 \pm 19 \%$ et $21 \pm 20$, respectivement). Notre étude présente un premier aperçu de la façon dont les phoques de l'Extrême-Arctique utilisent le fjord Petermann en évolution rapide et de l'influence des variables physiques sur leur répartition dans l'une des rares langues glaciaires de fjord restantes.

Mots clés : glacier Petermann; mammifères marins; langue glaciaire de fjord; phoques de l'Arctique; glace marine; Pusa hispida; Erignathus barbatus; Crystophora cristata; Pagophilus groenlandicus

Traduit pour la revue Arctic par Nicole Giguère.

\section{INTRODUCTION}

High Arctic glacial fjords and surrounding waters are vital habitats to many pagophilic (ice-loving) marine species, including marine mammals such as seals (Kovacs and Lydersen, 2008; Lydersen et al., 2014). Arctic marine mammal habitat refers to any area where these species rest, feed, socialize, mate, give birth, care for young, avoid predators, or migrate (Laidre et al., 2008). Ice, in both glacial and sea-ice forms, is a primary physical habitat feature of the Arctic environment and consequently influences nearly all aspects of life for seals, either through direct habitat selection or through seasonal migrations that coincide with changing sea-ice conditions. During late summer 2015, the multidisciplinary Petermann 2015 Expedition with the icebreaker Oden investigated the marine cryosphere, oceanography, and geology in the region of Petermann Fjord and adjacent Nares Strait in northwestern Greenland (Fig. 1). The primary marine field program consisted of geophysical mapping, sediment coring, and oceanographic station work. The geophysical mapping included a small component of seismic reflection profiling using acoustic sources. While in Canadian waters, the expedition was required to monitor marine mammals and mitigate potential effects of underwater noise, so a dedicated marine mammal observation component was also included. Marine mammal sighting data were collected throughout the expedition; however, only data collected during periods of non-seismic effort were included in this study. The potential for links between the physical environment and mammal distribution in Petermann Fjord led to investigating these connections and integrating the marine mammal component into the scientific program of the Petermann 2015 Expedition.

Our study objectives were to assess seal occurrence in Petermann Fjord and surrounding Nares Strait and seal distribution in relation to water depth and ice coverage. For this rarely studied, extremely remote, and rapidly changing region of northwestern Greenland, we attempt to provide a preliminary criterion for seal occurrence and habitat use during the summer season. We summarize and examine the occurrence in the ice-tongue fjord environment (ITFE) of Petermann Fjord and adjacent Nares Strait of four recorded seal species: bearded seal (Erignathus barbatus), ringed seal (Pusa hispida), harp seal (Pagophilus groenlandicus), and hooded seal (Crystophora cristata). Additionally, we examine seal distribution in relation to seafloor bathymetry and ice coverage to investigate potential habitat use of Petermann Fjord and surrounding waters.

\section{Ice-Tongue Fjords}

Since the mid-1990s, floating ice shelves in the Arctic (referred to as ice tongues when formed as narrow floating extensions of outlet glaciers in fjords) have experienced substantive size reductions. Reductions of the marine ice in general may have adverse implications for the marine ecosystem (Vincent et al., 2001; Rignot and Kanagaratnam, 2006; Bevan et al., 2012; Laidre et al., 2015; Mouginot et al., 2015). Arctic seals are especially affected, since they rely on sea ice as a platform for hauling out (resting), pupping, molting, and sub-ice foraging (Laidre et al., 2008, 2015). Fjords with ice tongues extending in front of outlet glaciers provide calmer, more stable sea-ice environments than fjords that lack ice tongues and where active outlet glaciers calve icebergs directly into the fjord (Nick et al., 2012). Over the last decade, the Petermann Glacier ice tongue has lost substantial mass through major calving events, most notably those in 2010 and 2012, which resulted in a $33 \mathrm{~km}$ retreat of the ice tongue and loss of nearly $40 \%$ of its former extent (Johannessen et al., 2011; Münchow et al., 2014) (Fig. 1). Also in western Greenland, an accelerated retreat phase of the Jakobshavn Glacier ice tongue $\left(69^{\circ} \mathrm{N}, 50^{\circ} \mathrm{W}\right)$ that began after 1997 culminated in its near complete disintegration, which caused significant marine cryospheric changes of the fjord environment (Joughin et al., 2004). Previously, the Jakobshavn ice tongue had remained relatively stable for nearly 35 years after a retreat of about $30 \mathrm{~km}$ from its Little Ice Age position in 1850 (Carbonell and Bauer, 1968; Pelto et al., 1989). Since the recent Jakobshavn breakup, icebergs have calved directly from the grounded margin of the fast-flowing outlet glacier, resulting in a mélange of icebergs, local tsunamis, and earthquakes attributed to icebergs violently entering the fjord and scraping the seafloor (Amundson et al., 2008). Although Petermann Fjord is one of the few remaining relatively stable ITFEs of Greenland, the recent major calving events, together with indications of inflowing warmer subsurface water (Münchow et al., 2014), suggest that it too has a high potential for complete ice-tongue breakup, with accompanying impacts on essential seal habitat. Glacial bays of the High Arctic, that is, the areas around the margins of outlet glaciers, or ice tongues, and associated fjords, provide vital foraging habitats for marine mammals 

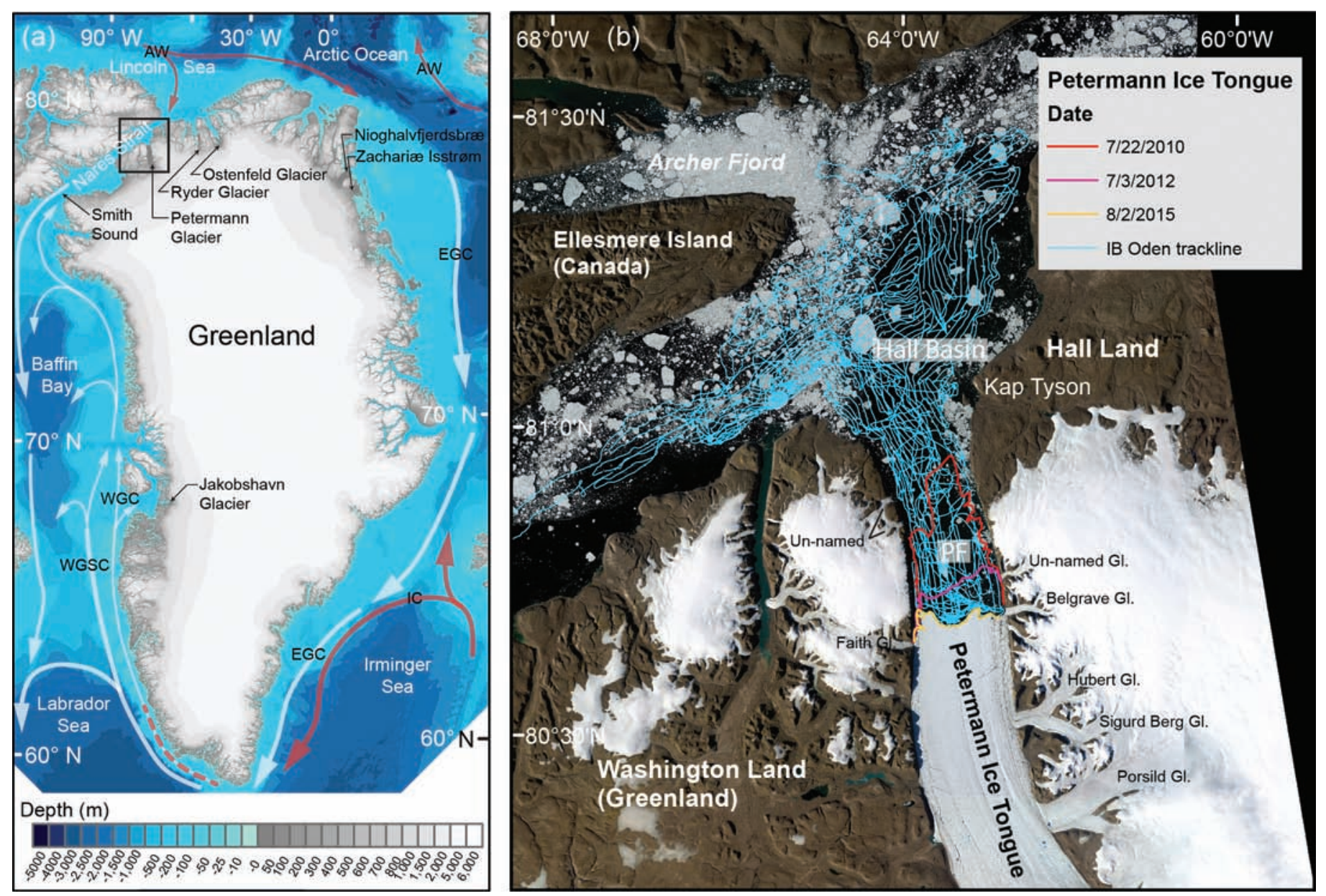

FIG. 1. Maps of Petermann Fjord situated in northwestern Greenland. (a) Overview of Greenland with the main study area outlined by a black box. The general ocean circulation patterns are illustrated by flow arrows ( $\mathrm{AW}=$ Atlantic Water; EGC $=$ East Greenland Current; IC $=$ Irminger Current; WGC $=$ West Greenland Current; WGSC = West Greenland Slope Current). Bathymetry from the International Bathymetric Chart of the Arctic Ocean (IBCAO, Jakobsson et al., 2012). (b) The main study area of Petermann Glacier and adjacent Hall Basin in Nares Strait and survey track of the icebreaker Oden (blue lines). Red (2010), pink (2012), and yellow (2015) lines depict the retreat of the ice-tongue margin from 2 July 2010 to 2 August 2015. The past extents of the Petermann ice tongue are digitized from Landsat images.

through the physical force of aggregating plankton and consequently fish (Laidre et al., 2008; Lydersen et al., 2014). Primary production and food web structure, and thus the availability of prey for pagophilic marine mammals, are greatly influenced by the extent of ice cover, water depth, seafloor substrate, bathymetry, and oceanography (Walsh, 2008).

\section{Petermann Fjord}

Petermann Fjord is located in northwestern Greenland at approximately $81^{\circ} \mathrm{N}, 61^{\circ} \mathrm{W}$ (Fig. 1). The glacier, a major outlet of the northwest sector of the Greenland Ice Sheet, terminates at the fjord head with a floating ice tongue approximately $50 \mathrm{~km}$ long and $18 \mathrm{~km}$ wide. Four additional, much smaller outlet glaciers terminate in the fjord along its steep sidewalls, seaward of the ice-tongue margin. Only the southeastern glacier (the Belgrave Glacier) has been named (Fig. 1). The two glaciers located on the western side terminate on the steep sidewalls and are hanging glaciers. The portion of Petermann Fjord accessible with a surface vessel (i.e., not covered by the ice tongue) is approximately $17-20 \mathrm{~km}$ wide and $37 \mathrm{~km}$ long, measured from the 2015 ice-tongue margin to the entrance where the fjord widens and meets Hall Basin in line with Kap Tyson (Fig. 1). The fjord continues as a cavity under the ice tongue for nearly $50 \mathrm{~km}$ from the 2015 ice tongue margin to the grounding line of Petermann Glacier.

A prominent bathymetric sill separates the inner fjord from Hall Basin but is deep enough to allow entry of warmer water. The recently observed yearly thinning of the ice tongue has been attributed to the inflow of warmer subsurface water of Atlantic origin (Johnson et al., 2011). This Atlantic water took the pathway through the Arctic Ocean and across Lincoln Sea before entering Nares Strait from the north (Fig. 1). Circulation of the upper water layer at the fjord mouth appears to be generally characterized by cyclonic gyre during the period of the year when the sea ice is mobile. The main outflow of this gyre occurs along the northeastern side of the fjord. Renewal of deep waters inside the prominent bathymetric sill occurs by spillover of the previously mentioned Atlantic water that traveled 
through the Arctic Ocean. Glacial meltwater is a prominent oceanographic feature of Petermann Fjord, specifically between depths of about 200 and $500 \mathrm{~m}$, of which the latter is the inferred approximate depth of the grounding line (Johnson et al., 2011). Although the ITFE may host both landfast ice and pack ice in a semi-enclosed area, Petermann Fjord does not host much multiyear landfast ice since katabatic winds (i.e., downslope winds off the glacier and fjord walls) efficiently flush the fjord of ice during peak summer months. This fact implies that the inner fjord may experience several ice-free days from about the beginning of August until September. However, sea ice (mixed with icebergs from the calving outlet glaciers along the fjord sides and from the ice tongue itself) covers the fjord for the remaining part of the year.

No dedicated marine mammal studies had taken place in Petermann Fjord before the 2015 expedition; therefore, it was unknown which species would be recorded. On the basis of their known circumpolar distribution, we anticipated encountering bearded seals, harp seals, hooded seals, and ringed seals. However, since the expedition occurred in August, concurrent with reported postbreeding and molting season for all four seal species, we did not expect to find pups and anticipated that Petermann Fjord would prove to be a summer foraging habitat.

\section{Bearded Seals}

Bearded seals are considered widely distributed throughout the Arctic and generally south of $80^{\circ} \mathrm{N}$ (Jefferson et al., 2015). Their range is typically limited to shallower coastal waters, and they are considered closely associated with ice (Lowry et al., 1980; Burns, 1981). The relatively tight coastal distribution is likely related to their shallow benthic feeding habits and their need for ice as a resting platform (Lowry et al., 1980; Burns, 1981; Hammill et al., 1991). Bearded seals prey on shrimp (Caridea spp.), clams (Tridacna spp.), crabs (Brachyura spp.), other benthic invertebrates, and fishes (Lowry et al., 1980). Pupping season generally occurs from mid-March to early May (Burns, 1981; Jefferson et al., 2015). Although primarily pelagic during the summer and fall, bearded seals may remain in or near the sea ice year-round (Burns, 1981).

\section{Harp Seals}

Harp seals are a gregarious North Atlantic and Arctic species (Kovacs and Lydersen, 2008). Throughout their range, they tend to inhabit waters over the continental shelf, remaining in association with sea ice for much of the year and preferring drifting, first-year ice with large open leads (Folkow et al., 2004; Kovacs and Lydersen, 2008). Their varied diet is known to include capelin (Mallotus villosus), mysids (Mysida spp.), shrimp, and krill (Euphausiacea spp.) (Beck et al., 1993; Hammill et al., 2005). Deployment of satellite transmitters on harp seals in spring found that they remained near the pack-ice edge during pupping and molting and moved into more offshore, ice-free waters during summer. Their summer distribution largely overlaps that of capelin, a main source of prey (Folkow et al., 2004). Harp seals congregate in large numbers for the pupping and breeding season in early spring, which is followed closely by an annual molt. After the molt, harp seals migrate north with the ice for the summer foraging season (Folkow et al., 2004; Jefferson et al., 2015).

\section{Hooded Seals}

Although hooded seals are known to be associated with pack ice, in the Greenland Sea they have been found to undertake pelagic excursions for many consecutive weeks, far from ice-filled waters, and they do not haul out (Folkow and Blix, 1999). There are three known spring breeding and pupping locations: one off the east coast of Canada, split between the Gulf of St. Lawrence and north of Newfoundland; a second group in Davis Strait; and a third in the Greenland Sea (Folkow and Blix, 1999). The MarchApril pupping season is followed by a late spring molt, after which hooded seals disperse for the summer, fall, and winter, living along the ice edge (Hammill, 1993; Folkow and Blix, 1995). The diet of hooded seals is not well known; however, stomach content analyses by Haug et al. (2007) show that adult seals prey on squid (Cephalopod spp.), as well as on many species of fish, including Greenland halibut (Reinhardtius hippoglossoides), polar cod (Boreogadus saida), and capelin.

\section{Ringed Seals}

Ringed seals inhabit all water depths in most of the Arctic Ocean and bordering seas and are closely associated with landfast ice and drifting pack ice (Burns, 1970; Reeves, 1998). Field studies of ringed seals in the Alaskan Beaufort Sea, Baffin Bay, and Svalbard, Norway, have shown that sea floor morphology, distance from the ice edge, and ice formation affect the habitat selection and distribution patterns of ringed seals (Smith and Stirling, 1975; Carlens et al., 2006; Krafft et al., 2006). As for the species previously discussed, pupping for ringed seals takes place in early spring and is followed by an annual molt. Although several studies have examined ringed seal distribution in spring, fewer data are available for the open-water season. However, it is thought that during the summer and early fall ringed seals concentrate at highest densities over shallow to middle depths $(100-200 \mathrm{~m})$ where ice cover is $40 \%-80 \%$ and prey availability is high (Freitas et al., 2008). In Svalbard, where ringed seals have been extensively studied, they feed intensively from late summer to early spring to replenish their fat losses during breeding and molting (Ryg et al., 1990). Feeding under the ice or in the upper part of the water column in depths of less than $50 \mathrm{~m}$, they are capable of diving to depths of over $250 \mathrm{~m}$ (Teilmann et al., 1999). Known to be prolific feeders, ringed seals prey on more than 30 different food species, 
including both fish and invertebrates, that vary by region and seasonally (Siegstad et al., 1998).

Challenges inherent in field research in the High Arctic limit our knowledge and understanding of marine mammal habitat use and distribution, specifically in the few remaining ITFEs of northwestern Greenland. Because of the extremely remote location and accessibility limited to the short openwater season, only fragments of the Petermann Fjord region seafloor and oceanography have been studied and mapped. No dedicated seal surveys have previously been conducted in this region, which limits our understanding of which seal species occur in and around the fjord and how seals use Petermann Fjord. The paucity of baseline information available makes it difficult to predict how the projected disappearance of the ice tongue in Petermann Fjord could influence habitat and distribution of seals. Our study provides a first look at High Arctic seals of Petermann Fjord and surrounding northwestern Greenland waters.

\section{METHODS}

Marine mammal occurrence and distribution data were collected in the course of daily vessel-based visual observations by one dedicated, trained biologist, who observed marine mammals from the portside bridge on the sixth deck of the icebreaker Oden, with eye height at $32 \mathrm{~m}$ above sea level. Observations were made for approximately 10 hours each day, typically between 0800 and 2100 UTC, with regular breaks to facilitate observer rest and limit fatigue. Observation effort totaled 239.4 hours (14361.8 min) for the 27 days (2 through 28 August 2015) in the survey area.

Systematic scanning was done alternating between the naked eye, handheld Fujinon $10 \times 50$ reticle binoculars, and Celestron $25 \times 100$ tripod-mounted binoculars. Sighting and environmental data were logged using Mysticetus ${ }^{\mathrm{TM}}$ Observation Software (Mysticetus) on a laptop linked to a GPS unit (www.mysticetus.com). Mysticetus displayed and logged positions and distances to marine mammal sightings based on the bearing and binocular reticle or estimated visual distance entries made by the observer. Marine mammal observations focused forward and to the sides of the vessel in an arc of $\sim 180^{\circ}$, but the observer also checked regularly for marine mammals astern of the vessel. Beaufort sea state was recorded at 3 or lower for more than $95 \%$ of the survey duration and thus was not incorporated as a factor affecting sightability. Daylight lasted 24 hours a day throughout the 2-28 August observations, and there were no periods of fog or limited visibility due to weather. The effects of glare were minimized by a $360^{\circ}$ bridgeviewing platform, sun protection blinds on the bridge windows, and polarized sunglasses. All marine mammals sighted were recorded and when possible photographed for identification purposes with a Canon EOS 4D digital camera and 100-400 mm lens.
Upon a sighting (single animal or group of animals), the following data were recorded:

Environmental data: Beaufort sea state, ice cover $(10 \%$ increments in the $\sim 180^{\circ}$ forward observation area to a distance of $2 \mathrm{~km}$ from the vessel), visibility $(\mathrm{km})$, and sun glare (in $\%$ of the $\sim 180^{\circ}$ forward observation area). Environmental data were recorded at the start and end of each watch and whenever an obvious change occurred in one or more of the environmental variables.

Seal sighting data: species, minimum, maximum and best estimate of seal count, number of juveniles and calves, individual behavioral events, initial behavior state (hauled out or in water), bearing and distance of the seals(s) relative to the vessel, sighting cue (what aspect of the seal drew the attention of the observer, e.g., body, splash).

The study area encompassed all of Petermann Fjord and the inlet area between Hall Land and Washington Land (Fig. 1). Vessel track-line paths were dictated by the objectives for mapping the sea floor, the sites chosen for sediment coring, and the locations of oceanographic stations. The result was somewhat irregular survey lines and uneven effort, with more tracking within Petermann Fjord than in surrounding waters (Fig. 1). Seafloor bathymetry was mapped using the Kongsberg EM122 $1^{\circ} \times 1^{\circ} 12 \mathrm{kHz}$ full ocean depth multibeam echo sounder installed in the icebreaker Oden. Meltwater plumes were recorded on the Oden's midwater split beam sonar using a Kongsberg EK 80 with an $18 \mathrm{kHz}$ transducer. Seaice information was acquired using synthetic aperture radar (SAR) satellite imagery with a resolution of $40 \times$ $40 \mathrm{~m}$ (Sentinel 1, SAR-C) and Landsat 8 imagery with a resolution of $15 \times 15 \mathrm{~m}$. Satellite images were downloaded to provide sea-ice snapshots as close as possible in time to seal sightings (i.e., within 12 hours). Usable Landsat 8 images were limited because the satellite passes over the study area infrequently and the images depend on cloudfree conditions. Seal sightings recorded by visual observers were mapped relative to sea-ice images for the five days with the highest daily sighting rates $(14,16,19,23$, and 25 August) to evaluate relationships between ice cover and the distribution and haul-out behavior of seals.

We standardized marine mammal sighting data by calculating sightings per unit of effort (SPUE) for pooled seal species (ringed, bearded, harp, and hooded seals). SPUE rates were based on the number of individual seals sighted per minute within grid cells of $4 \times 4 \mathrm{~km}$. The area of $4 \times 4 \mathrm{~km}$ was selected because it represents the maximum estimated area ( $2 \mathrm{~km}$ on each side of the vessel) in which an observer could sight a seal from the $32 \mathrm{~m}$ bridge height of the icebreaker Oden. We used a squared area to facilitate spatial calculation and display using tools available in the GIS software ArcGIS. Sighting rates were calculated for each of four seal species (ringed, bearded, harp, and hooded seals) and for all species pooled as number of individuals sighted per hour of observation effort.

We performed a chi-square goodness-of-fit test for significance in the number of sightings by species and 


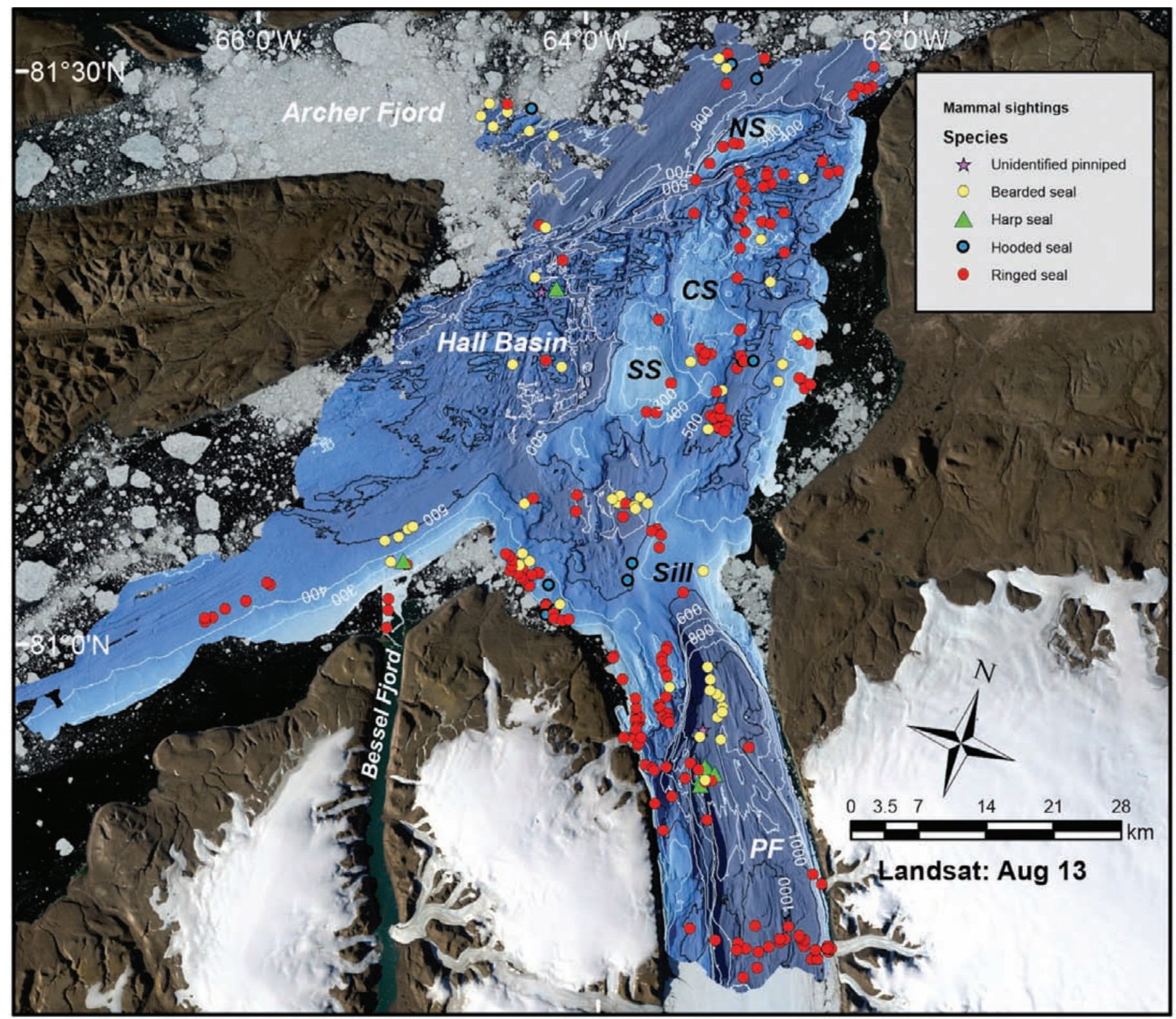

FIG. 2. Individual seals sighted from 2 to 28 August during the Petermann 2015 Expedition and bathymetry of survey area and Petermann Fjord. Three shoals (marked SS, CS, and NS) on the plateau in Hall Basin are shallower than $300 \mathrm{~m}$. At the entrance to Petermann Fjord, a prominent bathymetric sill (marked Sill) separates Hall Basin from the actual fjord (marked PF). This sill is deepest (443 m) on the southern side.

by species hauled out (on icebergs or on the ice tongue) versus in water. We performed one-way ANOVA (analysis of variance) and post hoc Tukey HSD (honest significant difference) tests on species by depth and species by percent ice coverage. Statistical analyses were performed using $\mathrm{R}$ 3.4.2 in RStudio 1.0.143. Sightings of individuals by depth were calculated using water depths obtained from the multibeam sonar. We calculated sightings of individuals by ice coverage using ice cover the observer recorded (by $10 \%$ increments to a distance of $2 \mathrm{~km}$ from the vessel) in the $\sim 180^{\circ}$ forward observation area.

\section{RESULTS}

\section{Petermann Fjord Physical Environment}

Petermann Fjord, adjacent Kennedy Channel, and Hall Basin of Nares Strait were systematically mapped with multibeam sonar in an approximately $3100 \mathrm{~km}^{2}$ area of the seafloor from the icebreaker Oden (Figs. 1 and 2). Results from the mapping component revealed a broad bathymetric plateau dominating Hall Basin's eastern region near Hall Land. Three shoals on the plateau (marked SS, CS, and NS in Fig. 2) are shallower than $300 \mathrm{~m}$, and north of this plateau the basin is deeper than $700 \mathrm{~m}$. The entrance to Petermann Fjord consists of a prominent bathymetric sill that separates the outer Hall Basin from the actual Petermann Fjord. The 
TABLE 1. Number of seal sightings, sighting rates, and percentage observed hauled out, by species.

\begin{tabular}{lccc}
\hline \hline Species & $\begin{array}{c}\text { No. sightings } \\
\text { (individuals) }\end{array}$ & $\begin{array}{c}\text { Sighting } \\
\text { rate }^{1}\end{array}$ & $\begin{array}{c}\text { \% Hauled } \\
\text { out (n) }\end{array}$ \\
\hline Bearded seal & 67 & 0.28 & $73(49)$ \\
Harp seal & 15 & 0.06 & $47(7)$ \\
Hooded seal & 12 & 0.05 & $50(6)$ \\
Ringed seal & 213 & 0.89 & $6(13)$ \\
Unidentified seal & 5 & 0.02 & $0(0)$ \\
Total & 312 & 1.30 & $24(75)$ \\
\hline \hline
\end{tabular}

${ }^{1}$ Sighting rates are based on the number of individuals seen per hour of observation effort.

deepest part of the sill is on the southern side at $443 \mathrm{~m}$ (Fig. 2). Petermann Fjord is more than $1000 \mathrm{~m}$ deep in places and is flanked by steep sidewalls. Results from the sediment coring and sub-bottom profiling component of the expedition (not reported here) generally show that the deeper sections below approximately $500-600 \mathrm{~m}$ are composed of soft sediments, while the shallower areas consist of harder seafloor, with occasional blocks of rocks that have fallen down from the surrounding fjord walls and additionally from outcropping bedrock. The seabed of the deep inner fjord consists of extremely soft sediments typical for environments near or under an ice tongue or ice shelf. When the icebreaker Oden reached Petermann Fjord on 3 August, a dense sea-ice cover was blocking the entrance to the fjord. Katabatic winds had cleared an area extending approximately $25 \mathrm{~km}$ in front of the ice-tongue margin. On 3 August, a section of the ice-tongue margin approximately $3 \mathrm{~km}$ wide had calved, eventually breaking into several smaller icebergs. Mainly open-water conditions, with some drifting sea ice and icebergs, prevailed for the duration of the expedition. The sea-ice conditions in Hall Basin were quite variable, however, with generally denser coverage on the Canadian side of the strait. The icebreaker Oden's midwater split-beam sonar recorded scattering likely caused by marine organisms (e.g., small schooling fish, phytoplankton, and zooplankton) in the meltwater plumes near all the margins of the outlet glaciers.

\section{Marine Mammals}

Four species of seals were observed: bearded, harp, hooded, and ringed seals. A total of 312 seals were recorded, and ringed seals were recorded significantly more often than the other three seal species $\left(\chi^{2}=347.4, \mathrm{df}=3\right.$, $p<0.001, \mathrm{n}=307)$. Sighting rates were highest for ringed seals ( 0.89 individuals/hour), followed by bearded seals (0.28 individuals/hour). Sighting rates were lowest for harp (0.06 individuals/hour) and hooded (0.05 individuals/hour) seals (Table 1). A total of five seals were not identified to species because they were too far from the vessel when observed. No pups were recorded. When seal sightings were pooled, $24.02 \%$ of the seals were hauled out (i.e., on floating

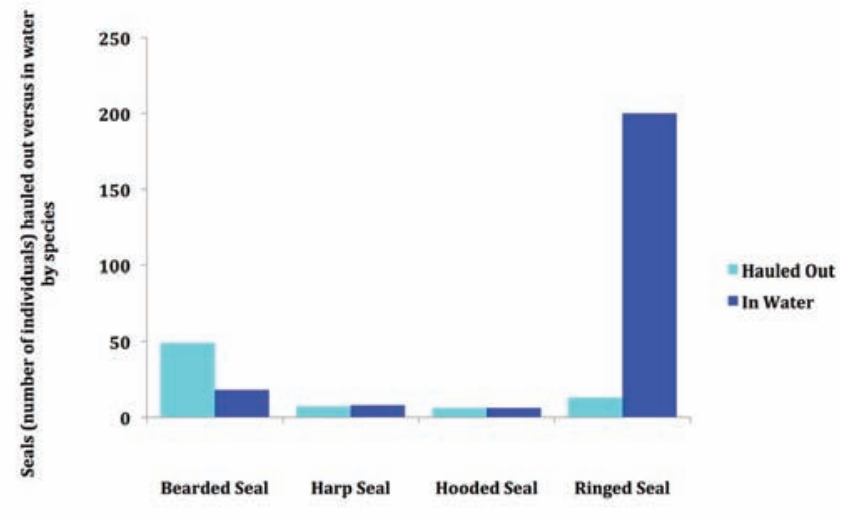

FIG. 3. Seals (number of individuals) hauled out and in water, by seal species.

icebergs or the Petermann ice tongue). The number of seals hauled out versus in water varied significantly by species $\left(\chi^{2}=133.1, \mathrm{df}=3, p<0.001, \mathrm{n}=307\right)$. Bearded seals were more frequently hauled out $(73.1 \% \mathrm{n}=49)$ whereas ringed seals were found almost exclusively in the water $(93.9 \%$, $\mathrm{n}=200$; Fig. 3).

Sightings per unit effort were calculated for each $4 \times$ $4 \mathrm{~km}$ grid cell in Petermann Fjord and surrounding Nares Strait. Figure 4 shows distributions of seals within the study area depicted by color-coded SPUE ranging from "high" (0.75 sightings per minute) to "low" (0.002 sightings per minute) per $4 \times 4 \mathrm{~km}$ grid cell. Within Petermann Fjord, SPUE was highest along the ice-tongue margin and in front of Belgrave Glacier and the unnamed glacier at the southeast corner of the fjord and the two unnamed glaciers at the northwest end of the fjord (Fig. 1). Although ringed seals were observed throughout the fjord, there was a clear increase in SPUE of ringed seals along the ice shelf edge, fjord walls, and near outlet glaciers (Fig. 4). On two occasions, ringed seals were observed hauled out on the flat sections in meltwater areas on the Petermann ice tongue itself. There was a clear increase in occurrence of both ringed and bearded seals along the bathymetric sill at the entrance to the fjord. In the adjacent waters of Nares Strait, seal SPUE was highest near the entrance to Bessel Fjord and in Hall Basin, with lower SPUE near the entrance to Archer Fjord in Lady Franklin Bay (Fig. 4).

\section{Water Depth}

We mapped seal sightings in relation to bathymetry obtained from the multibeam echo sounder and assessed depth for each sighting (Fig. 2). For all species pooled, mean water depth where seals were found was $526 \pm 250 \mathrm{~m}$; however, mean water depth preference differed by species. Harp and bearded seals were found in the deeper mean water depths (663 $\pm 366 \mathrm{~m}$ and $598 \pm 259 \mathrm{~m}$, respectively; Table 2; Fig. 5), while hooded and ringed seals were found in shallower mean water depths $(490 \pm 163 \mathrm{~m}$ and 496 $\pm 235 \mathrm{~m}$, respectively; Table 2). We found a statistically significant difference between species and mean water 


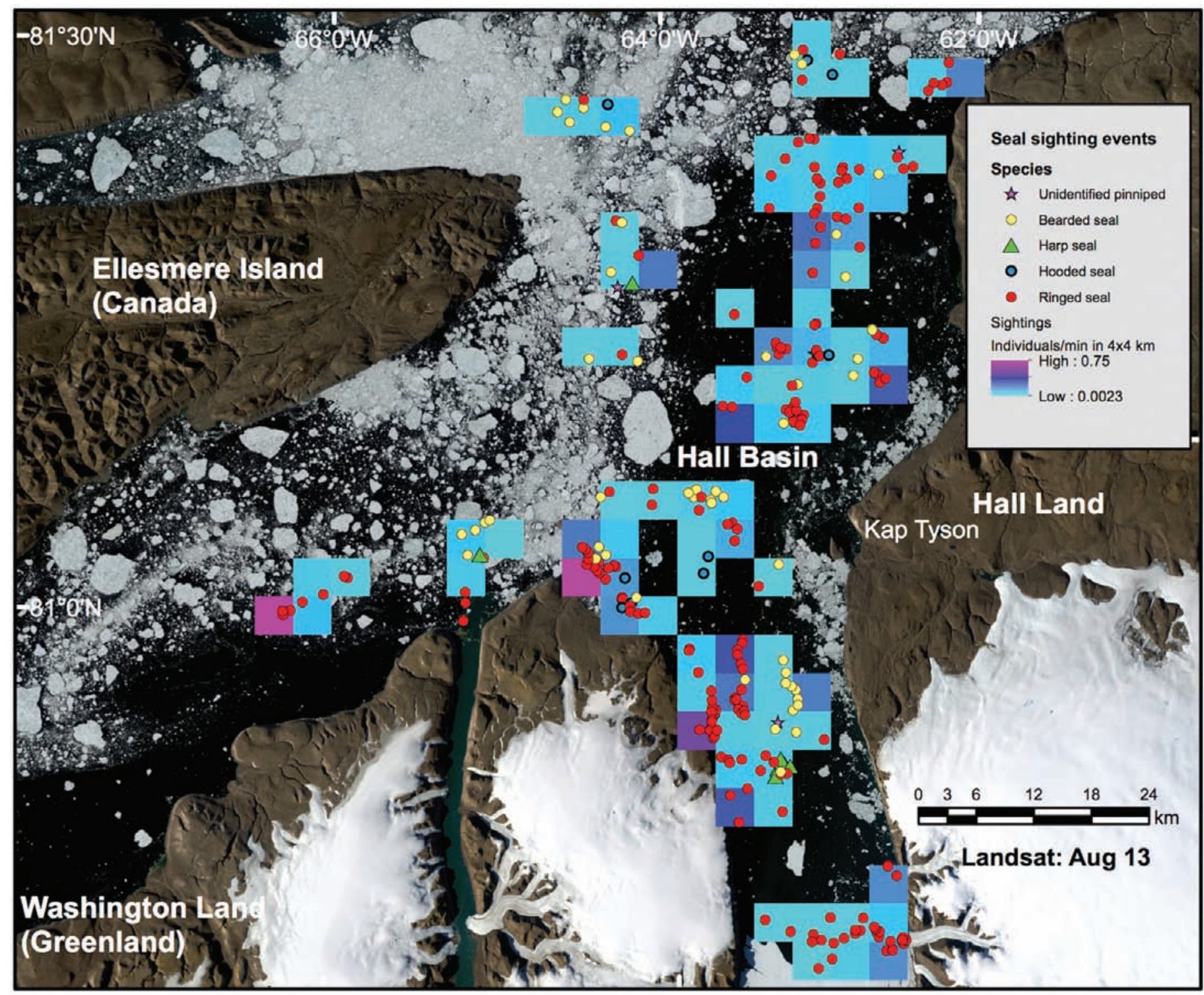

FIG. 4. Seals (number of individuals) observed, by seal species, and color-coded SPUE (sightings per unit of effort) in each $4 \times 4 \mathrm{~km}$ grid cell.

depth preference as determined by one-way ANOVA $(\mathrm{F}=$ $4.641, p=0.00345)$. A post hoc Tukey HSD test showed that the mean water depth preferences of ringed and bearded seals differed significantly $(p<0.05)$. However, mean water depth preference was not significantly different between the other two species (Fig. 5).

\section{Sea Ice}

We also assessed seal sightings in relation to percent ice coverage. For all species pooled, mean ice coverage where seals were found was $42 \pm 21 \%$. Mean percent ice coverage preference varied by species. Harp and bearded seals were found in areas of greater mean ice coverage $(65 \pm 14 \%$ and $50 \pm 21 \%$, respectively; Table 2; Fig. 6) than ringed and hooded seals $(38 \pm 19 \%$ and $21 \pm 20 \%$, respectively; Table 2). We found a statistically significant difference between species and mean percent ice coverage preference as determined by one-way ANOVA ( $\mathrm{F}=14.42, p<0.001)$. A post hoc Tukey HSD test showed that the mean percent ice coverage preference between ringed and bearded, ringed and harp, and harp and bearded seal sightings differed significantly ( $p<0.001, p<0.001$, and $p<0.05$, respectively); however, we found no significant difference between hooded seal sightings and the other three species (Fig. 6).

Seal sightings were mapped relative to sea ice for the five days (14, 16, 19, 23, and 25 August) when sighting rates were highest (Fig. 7, Table 3). The location of each SAR sea-ice image within the survey area is depicted in Figure 7A, and a summary for each day is provided below.

On 14 August, the sea-ice image taken at 12:32 (Fig. 7B) shows seals recorded in Hall Basin, northeast of Petermann Fjord. Mean ice coverage during the observation period was $43 \%$. Ringed seals, all of which were in the water, accounted for $80 \%$ of the sightings. Of the seven bearded 
TABLE 2. Mean bottom depth of water and ice coverage, by species.

\begin{tabular}{lcccc}
\hline \hline Species & Mean water depth $(\mathrm{m})$ & Range $(\mathrm{m})$ & Mean ice coverage $(\%)$ & Range $(\%)$ \\
\hline Bearded seal & $598 \pm 259$ & $167-1101$ & $50 \pm 21$ & $10-95$ \\
Harp seal & $663 \pm 366$ & $297-1095$ & $65 \pm 14$ & $50-80$ \\
Hooded seal & $490 \pm 163$ & $221-751$ & $21 \pm 20$ & $20-95$ \\
Ringed seal & $496 \pm 235$ & $49-1078$ & $38 \pm 19$ & $5-95$ \\
\hline \hline
\end{tabular}

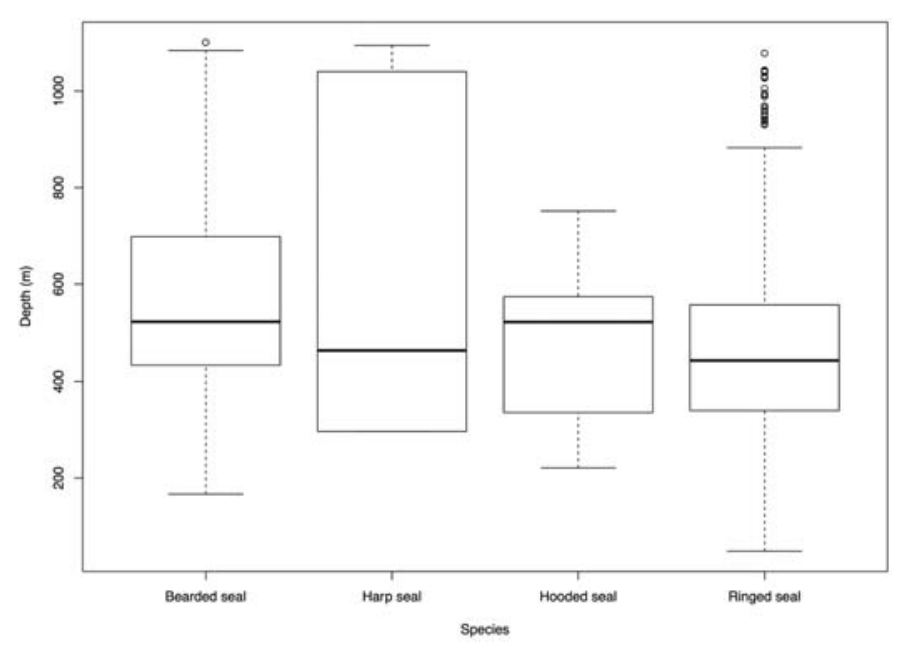

FIG. 5. Seals (number of individuals) observed, by bottom depth of water (m).

seals sighted, $57 \%$ were hauled out. Throughout this observation period, bearded and ringed seals were recorded within a distance of less than $1 \mathrm{~km}$ of each other, showing a mixed species association.

On 16 August, the sea-ice image taken at 12:17 (Fig. 7C) shows seal sightings northwest of Petermann Fjord, outside the fjord sill. Mean ice coverage during the observation period was $28 \%$. Ringed seals accounted for $79 \%$ of the sightings, and all were in the water. Three hooded seals, also in water, were also sighted. Throughout this observation period, a cluster of bearded, ringed, and hooded seals within $3 \mathrm{~km}$ of each other was recorded, showing a mixed species association.

On 19 August, the sea-ice image taken at 20:50 (Fig. 7D) shows seal sightings in Lady Franklin Bay near the entrance to Archer Fjord. Mean ice coverage during the observation period was $91 \%$. Bearded seals accounted for $72 \%$ of the recorded seals. Nearly all $(91 \%)$ ringed seals were observed hauled out, with only one ringed seal group observed in the water. Throughout this observation period, a cluster of bearded, ringed, and hooded seals within $4 \mathrm{~km}$ of each other was recorded, showing a mixed species association.

On 23 August, the sea-ice image taken at 12:09 (Fig. 7E) shows seal sightings in Petermann Fjord. The sea ice image indicates ice cover of $20 \%$ due to a $4 \times 8 \mathrm{~km}^{2}$ ice flow positioned in the northwest entrance to the fjord. We recorded 13 bearded seals, of which 10 were hauled out on the large ice sheet, and the remaining three were within $200 \mathrm{~m}$ of the ice. On this day the farthest distance of a bearded seal into the fjord (i.e., towards the ice-tongue margin) during the survey was recorded, $\sim 18 \mathrm{~km}$ from the ice-tongue margin.
On 25 August, the sea-ice image taken at 11:51 (Fig. 7F) displays seal sightings at the entrance to Petermann Fjord outside the sill. Mean ice cover during this observation period was $50 \%$. Eight groups $(80 \%)$ of the sightings were bearded seals, six of which were hauled out. Throughout this observation period, bearded and ringed seals were recorded within $2 \mathrm{~km}$ of each other, showing mixed species association.

\section{DISCUSSION}

Our findings from the 2015 expedition to northwestern Greenland represent the first look at seals (and, to our knowledge, the only seal data available) for the Petermann Fjord area, a rare ITFE in an understudied region of the Arctic. Prior to this expedition, no dedicated marine mammal studies had taken place in Petermann Fjord, and as a result, no baseline data on marine mammal occurrence and distribution existed for the area. Our findings established that four species of Arctic seals (ringed, bearded, harp, and hooded seals) inhabit Petermann Fjord and the adjacent Nares Strait region. Ringed seals were the most abundant, followed by bearded seals. There were few sightings of hooded and harp seals (less than 20 each). Overall, we found that nearly three-quarters of the seals were recorded in water, with the remaining one-quarter hauled out on ice. All four species were observed both in water and hauled out, suggesting that High Arctic seals use Petermann Fjord and the surrounding waters of Nares Strait as summer foraging and resting habitats after the pupping and molting season. We found differences in behavior (hauled out vs. in water) between species. Ringed seals were recorded almost exclusively in water, whereas bearded seals were recorded mostly hauled out. These results provide a preliminary criterion for seal summer habitat use in this rarely studied region of northwestern Greenland. As anticipated, given the late summer timeframe of the expedition, our results corresponded with what would be expected in the post-breeding and molting periods. We did not record any pups or breeding and molting behaviors. It is important to note that results from this study provide a glimpse of only one season and one year; thus, seasonal and interannual trends are unknown.

We found significant differences in species occurrence by mean water depth and sea ice concentration. Bearded and harp seals were found at greater mean water depths and in areas of higher mean ice coverage. Hooded and ringed seals were found in shallower waters and areas of lower 


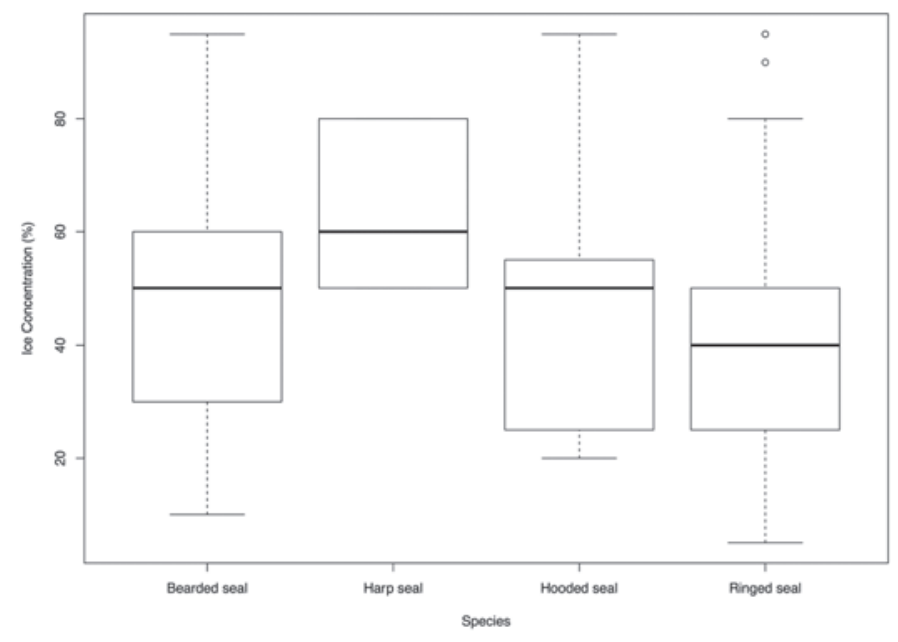

FIG. 6. Seals (number of individuals) observed, by ice concentration (\%).

mean ice coverage. It is important to note relative to seals and ice coverage that a smaller proportion of ice coverage could reduce the area available for seals to haul out, and a higher proportion of ice coverage could reduce the in-water area. In addition, the seal detection rate can be affected by sea ice coverage, as seals are easier to spot when hauled out on ice than when in the water.

\section{Ringed Seals}

Most ringed seal studies in the High Arctic have been focused in the Norwegian archipelago of Svalbard, where they are the most abundant marine mammal species and demonstrate extreme seasonal site fidelity in summer foraging areas. In Svalbard ringed seals leave the fjords during summer to feed offshore in the Barents and Greenland Seas, returning the following spring (Lydersen, 1998). Satellite tracking data indicate that after molting, ringed seals in Svalbard follow two distinct movement paths: some seals move offshore to areas of $40 \%-80 \%$ ice coverage, while others spread out along the coasts of Svalbard, concentrating near glacial fronts (Freitas et al., 2008). In both cases, Svalbard ringed seals remain in areas characterized by high food concentrations and ice coverage that provides habitat suitable for resting. Therefore, prey availability and ice coverage are two key factors in habitat selection for Arctic ringed seals, and they exhibit site fidelity, frequenting the same areas for foraging.

The ringed seals observed in and around Petermann Fjord and Nares Strait were in areas where mean ice coverage was approximately $40 \%$. Most ringed seals (more than 90\%) were observed in water with potential for foraging and a clear association with the ice-tongue margin, or in front of outlet glaciers. Ringed seals were repeatedly observed in front of the ice-tongue margin and on a few occasions hauled out in small riverbeds on Petermann Glacier itself. In the fjords of Svalbard, Lydersen et al. (2014) suggested that seal distribution was correlated with tidewater glacial fronts because of the presence of
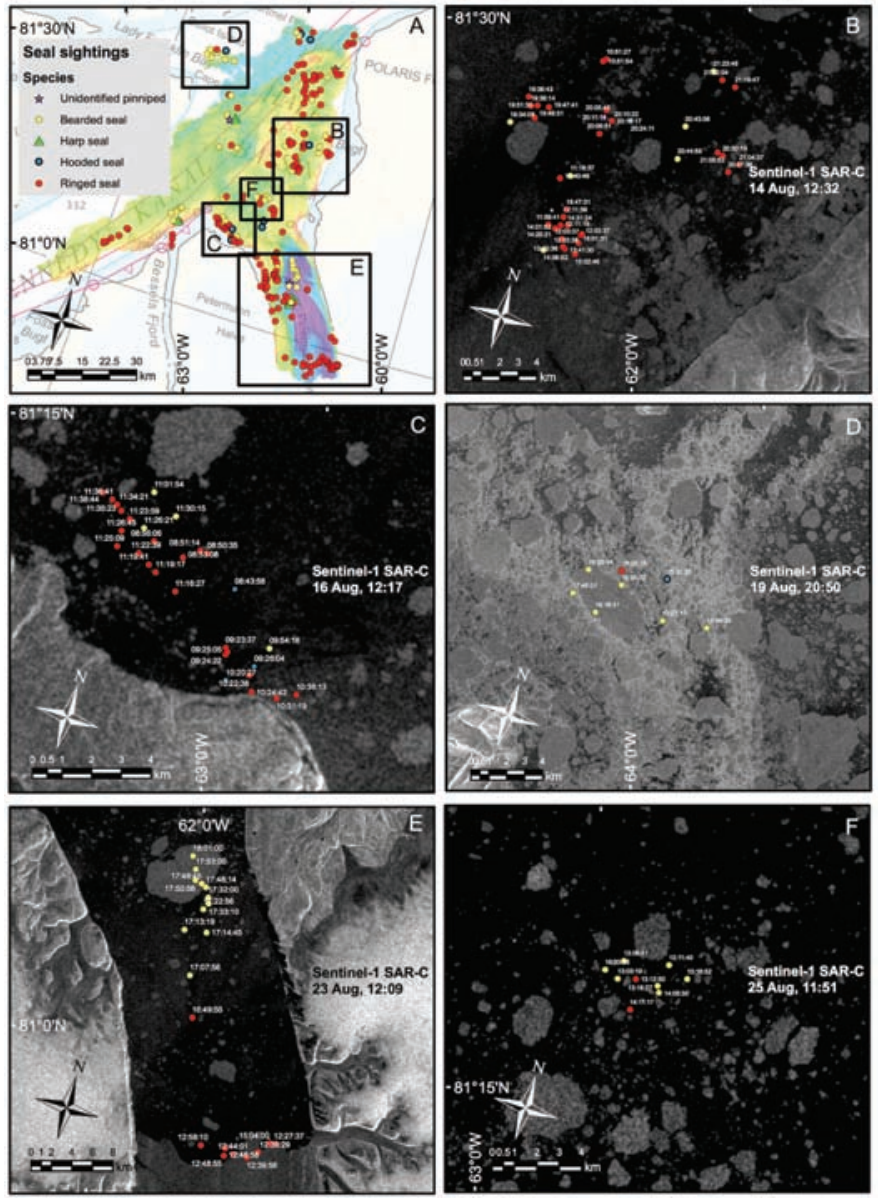

FIG. 7. Sea ice and seal sightings. A: Map indicating areas shown in sea ice images in panels B: 14 August, C: 16 August, D: 19 August, E: 23 August, and F: 25 August.

sub-glacial freshwater plumes. Tidewater glacial fronts are associated with freshwater outflows and river plumes, where biomass proliferation is thought to be high. The associated continuous upwelling of freshwater generates a movement of nutrients needed by phyto- and zooplankton from outer and deeper fjord waters towards the glacial front (Lydersen et al., 2014). During our study, scatters thought to be the presence of marine organisms (e.g., small schooling fish, phyto- and zooplankton) were clearly recorded on the icebreaker Oden's midwater split-beam sonar in the subglacial freshwater plumes in front of the Petermann and outlet glaciers. As no water sampling was done, we cannot exclude that the observed scatters in the sonar images could also be associated with plankton, or a combination of plankton and sediment-laden meltwater from the glacier. It is possible that our observations of ringed seals near the glacial fronts in Petermann Fjord are associated with freshwater glacial discharges in a pattern similar to the one found in Svalbard fjords.

Because our dataset is limited to one season and only one year, it is unknown whether ringed seals remain in Petermann Fjord and surrounding waters throughout the year or move to other locations for pupping and molting. 
TABLE 3. Data from sea ice images for five days (14, 16, 19, 23, and 25 August 2015) selected as those with the highest daily sighting rates to evaluate relationships between ice cover and the distribution and haul-out behavior of seals.

\begin{tabular}{|c|c|c|c|c|c|c|c|c|}
\hline Date & Image & Mean ice cover & Sea ice image time & Observation period & Seal Species & Hauled Out & In Water & Total \\
\hline \multirow[t]{3}{*}{14 Aug } & $7 \mathrm{~B}$ & $43 \%$ & $12: 32$ & $10: 51-21: 23$ & Bearded & 4 & 3 & 7 \\
\hline & & & & & Hooded & 0 & 2 & 2 \\
\hline & & & & & Ringed & 0 & 36 & 36 \\
\hline \multirow[t]{3}{*}{16 Aug } & $7 \mathrm{C}$ & $28 \%$ & $12: 17$ & $8: 42-11: 36$ & Bearded & 1 & 3 & 4 \\
\hline & & & & & Hooded & 0 & 3 & 3 \\
\hline & & & & & Ringed & 0 & 27 & 27 \\
\hline \multirow[t]{3}{*}{19 Aug } & 7D & $91 \%$ & $20: 50$ & $14: 59-17: 48$ & Bearded & 8 & 0 & 8 \\
\hline & & & & & Hooded & 1 & 0 & 1 \\
\hline & & & & & Ringed & 1 & 1 & 2 \\
\hline \multirow[t]{2}{*}{23 Aug } & $7 \mathrm{E}$ & $20 \%$ & $12: 09$ & $12: 36-18: 01$ & Bearded & 10 & 3 & 13 \\
\hline & & & & & Ringed & 0 & 9 & 9 \\
\hline \multirow[t]{2}{*}{25 Aug } & $7 \mathrm{~F}$ & $50 \%$ & $11: 51$ & $13: 03-16: 33$ & Bearded & 6 & 2 & 8 \\
\hline & & & & & Ringed & 1 & 1 & 2 \\
\hline
\end{tabular}

Similarly, because our survey was limited to one month of one year and was based on visual observations only (i.e., tagging did not take place), it is unknown whether the seals return to Petermann Fjord annually. However, it would be expected that their behavior would correspond to trends found in Svalbard; therefore, it is possible that some ringed seals exhibit site fidelity to Petermann Fjord and surrounding Nares Strait for summer foraging.

\section{Bearded Seals}

Unlike that of ringed seals, bearded seal distribution did not appear to correlate with the ice-tongue margin or outlet glaciers and was nearly exclusively free-ice dependent (i.e., closely associated with ice floes). Most ( $80 \%$ ) of the bearded seal sightings occurred outside Petermann Fjord. Bearded seals were observed within Petermann Fjord on only two dates and totaled 14 animals, all of which were over $18 \mathrm{~km}$ from the ice-tongue margin. On 23 August, 13 bearded seals were recorded hauled out on or within $200 \mathrm{~m}$ of a large $(4 \times 6 \mathrm{~km})$ ice sheet. As mainly open-water conditions prevailed in the fjord throughout the expedition, this large ice sheet had moved into the fjord one day prior and was propelled back out across the sill by katabatic winds within 48 hours.

Bearded seals were found in areas of higher ice concentration than ringed seals. Our results suggest that within Petermann Fjord bearded seals were exclusively associated with ice movement (i.e., moving into and out of the fjord with the ice). Bearded seals were found on average in water with bottom depths of $\sim 600 \mathrm{~m}$, significantly deeper than water depths where we found the three other seal species. This was surprising because bearded seals are thought to be predominantly benthic feeders that prefer areas of water no deeper than $200 \mathrm{~m}$ (Burns, 1981). Hammill et al. (1991) found that when their spring ice platforms used for nursing drifted out over deeper waters, bearded seals actively left the pupping ice and transited back into shallower areas. With average water depths of more than 500 m, Petermann Fjord would not be considered an ideal pupping and lactation habitat for bearded seals, known to typically pup in habitat that consists of small floes overlying shallow water (Hammill et al., 1991). Most (more than $70 \%$ ) of the bearded seals we observed were hauled out. This might suggest that bearded seals remain ice-associated when in or near Petermann Fjord, or venture into deeper waters when ice for hauling out and resting is available nearby.

\section{Harp and Hooded Seals}

Harp and hooded seals were observed much less frequently than ringed and bearded seals. In total, 15 harp seals were recorded, either in open leads in the ice outside Petermann Fjord, in Nares Strait, or hauled out on ice floes inside the fjord. This pattern coincides with known literature that depicts harp seals as gregarious, with a broad range in open ice-free waters. However, our findings suggest that harp seals use Petermann Fjord as a haul-out location, though infrequently.

To our knowledge there are no published records of hooded seals in Nares Strait or as far north as Petermann Fjord. Most literature reports that the northern extent of the hooded seal range in western Greenland is limited to Davis Strait and Baffin Bay (Hammill, 1993; Kapel, 1995). We recorded 12 hooded seals in the survey area, which suggests that hooded seals range farther north during the open-water season than previously published records show. However, the northern extension of the hooded seal's range is not surprising, as these seals are thought to disperse after the annual molt and cover an extensive range north and south of the North Atlantic (Folkow and Blix, 1995; Kapel, 1995). Our results correspond with reports that during the open-water season, hooded seals inhabit the outer edges of pack ice.

\section{Mixed-Species Associations}

In the sea-ice images, we found multiple examples of ringed, bearded, and hooded seals in close association with one another at distances under $1 \mathrm{~km}$. Mixed species associations and sympatric cohabitation of a similar habitat 
often suggest specialized ecological niches that serve to minimize interspecific competition for food and other important limited resources (Stensland et al., 2003). In Petermann Fjord, complementary habitat use and ecological niches of bearded seals and ringed seals are possibly based on dietary variance that manifests in differential use of the physical setting. However, additional studies would be needed to further elucidate potential ecological niches within the ITFE.

\section{Implications of Changing Ice for Marine Mammals}

Transformations and further reduction of the ice mass in Petermann Fjord may adversely affect the availability of important seal habitat. Glacier margin retreat associated with climate change may unfavorably influence the habitat use and distribution of marine mammals in this High Arctic fjord (Laidre et al., 2008; Bevan et al., 2012; Lydersen et al., 2014). Lydersen et al. (2014) suggested that in Svalbard, climate change is causing a decrease in both the number of glaciers calving into the ocean and the total length of calving fronts around the Archipelago. This potential decrease in glaciers calving and length of calving fronts, along with a lack of spring sea ice in front of glaciers in fjords during the last decade, is resulting in a near-zero pup production of ringed seals, considered a keystone predator for the ecosystem. Greenland has more than 30 large marine-terminating outlet glaciers, of which four currently end in floating ice tongues (Box and Decker, 2011). These four do not include Zachariæ Isstrøm in northeastern Greenland, which lost its ice tongue in 2015 after eight years of decay (Mouginot et al., 2015), or Jakobshavn Glacier, which had already experienced a near complete ice tongue disintegration by 2003 (Joughin et al., 2004). The ice tongues of Greenland exist in deep fjords, commonly inside bathymetric sills that may protect them from inflow of warmer subsurface water. In the fjord, the ice tongue exerts a buttressing effect on the feeding ice stream and prevents iceberg calving directly from an ice cliff, which otherwise forms at the ice-stream margin. The absence of an ice tongue in front of a marine-terminating, fast-flowing outlet glacier commonly leads to a fjord that during most of the year is filled with an ice mélange consisting of sea ice and irregular calved icebergs. In contrast, in a fjord with an ice tongue, the peak summer period may include weeks of ice-free conditions in front of the ice-tongue margin, as we observed in Petermann Fjord, while the remainder of the year is dominated by a relatively calm sea-ice environment. Calving from an ice-tongue margin is generally much less frequent than calving from an ice cliff.

It is clear that changing from an ITFE to an environment where icebergs calve directly from an ice cliff will greatly affect the fjord and subsequently, the marine mammal habitat. In Petermann Fjord, the recent large calving events in 2010 and 2012, representing a loss of $40 \%$ ice mass (Johannessen et al., 2011; Münchow et al., 2014), highlight the instability of this environment. Additionally, warmer water flowing over the sill into the inner fjord has been observed and linked to warming Atlantic water traveling through the Arctic Ocean to reach Nares Strait and Petermann Fjord (Münchow et al., 2014). These warm pulses from the Atlantic to the Arctic Ocean are recorded on decadal scales (e.g., Woodgate et al., 2001; Dmitrenko et al., 2008). Ice-associated seals are considered particularly susceptible and may be the first to change their distribution and habitat use in response to such physical changes to the Arctic environment (Tynan and DeMaster, 1997). Ice-associated seals have therefore been considered an indicator species for changing Arctic conditions (Tynan and DeMaster, 1997; Laidre et al., 2015). In some regions, ringed seals are already showing downward trends in rates of reproduction and neonatal survival that are thought to be linked to changes in sea-ice conditions and other major ecosystem shifts, although these relationships are inadequately understood (Ferguson et al., 2005; Stirling, 2005).

\section{CONCLUSION}

While the direct link to climate change remains a hypothesis, the observed recent warm pulses of Atlantic water into the Arctic Ocean increase the likelihood that the marine mammals inhabiting Petermann Fjord may experience a drastic environmental change within the next few decades. Increasing our understanding of seal occurrence and habitat use in these fragile and rare environments provides criteria with which to better monitor future transformations of the High Arctic. Iceassociated seals are considered particularly susceptible to the changing Arctic. Our study provides an initial profile of a rare ITFE and information on which marine mammals occur within and around Petermann Fjord. We offer a preliminary understanding of how physical variables influence seal occurrence in one of the few remaining icetongue fjord environments of northwestern Greenland. There is still much to understand about Petermann Fjord and marine mammal habitat use of this remote region. Further research on temporal and seasonal trends, foraging patterns, and prey availability could offer valuable insight into how this fjord functions as a marine mammal habitat and how changes to the ITFE (i.e., loss of the ice shelf itself) could potentially affect the marine species that inhabit it. It is clear, however, that the ITFE is a fragile, rare, and fast-changing habitat populated by relatively high numbers of seals that may be adversely affected if climate change results in its loss. Our results contribute to a growing database indicating that pagophilic pinnipeds are being affected by global reductions in Arctic ice cover and associated habitat changes. 


\section{ACKNOWLEDGEMENTS}

We thank the U.S. National Science Foundation Polar Programs, NASA, UNAVCO, CH2M Polar Field Services (Jessy Jenkins), the Polar Geospatial Center (George Roth), the British Antarctic Survey, GEUS, the Swedish Polar Research Secretariat (Ulf Hedman), and the Swedish Maritime Administration (Captain Mattias Petersson and crew of the icebreaker Oden). We thank Andreas Münchow (College of Earth, Ocean and Environment) for his collaboration. We thank Anne Jennings (INSTAAR and Department of Geological Sciences), Andrew Lomac-MacNair, and Arctic's anonymous reviewers, whose suggestions greatly improved the manuscript. We would like to thank Smultea Environmental Sciences for their support during the expedition and the development of this manuscript. Finally, we thank all those involved in the Petermann 2015 Expedition.

\section{REFERENCES}

Amundson, J.M., Truffer, M., Lüthi, M.P., Fahnestock, M., West, M., and Motyka, R.J. 2008. Glacier, fjord, and seismic response to recent large calving events, Jakobshavn Isbræ, Greenland. Geophysical Research Letters 35(22), L22501. https://doi.org/10.1029/2008GL035281

Beck, G.G., Hammill, M.O., and Smith, T.G. 1993. Seasonal variation in the diet of harp seals (Phoca groenlandica) from the Gulf of St. Lawrence and western Hudson Strait. Canadian Journal of Fisheries and Aquatic Sciences 50(7):1363 - 1371. https://doi.org/10.1139/f93-156

Bevan, S.L., Luckman, A.J., and Murray, T. 2012. Glacier dynamics over the last quarter of a century at Helheim, Kangerdlugssuaq and 14 other major Greenland outlet glaciers. The Cryosphere 6(5):923-937. https://doi.org/10.5194/tc-6-923-2012

Box, J.E., and Decker, D.T. 2011. Greenland marine-terminating glacier area changes: 2000-2010. Annals of Glaciology 52(59):91-98. https://oi.org/10.3189/172756411799096312

Burns, J.J. 1970. Remarks on the distribution and natural history of pagophilic pinnipeds in the Bering and Chukchi Seas. Journal of Mammalogy 51(3):445-454. https://doi.org/10.2307/1378386

- 1981. Bearded seal Erignathus barbatus Erxleben, 1777. In: Ridgway, S.H., and Harrison, R.J., eds. Handbook of marine mammals, Vol. 2: Seals. 145-170.

Carbonnell, M., and Bauer, A. 1968. Exploitation des couvertures photographiques aériennes répétées du front des glaciers vêlant dans Disko Bugt et Umanak Fjord, Juin-Juillet 1964. Technical Report 3, Expedition glaciologique internationale au Groenland (EGIG). Meddelelser om Grønland 173(5).

Carlens, H., Lydersen, C., Krafft, B.A., and Kovacs, K.M. 2006. Spring haul-out behavior of ringed seals (Pusa hispida) in Kongsfjorden, Svalbard. Marine Mammal Science 22(2):379-393.

https://doi.org/10.1111/j.1748-7692.2006.00034.x
Dmitrenko, I.A., Polyakov, I.V., Kirillov, S.A., Timokhov, L.A., Frolov, I.E., Sokolov, V.T., Simmons, H.L., Ivanov, V.V., and Walsh, D. 2008. Toward a warmer Arctic Ocean: Spreading of the early 21st century Atlantic Water warm anomaly along the Eurasian Basin margins. Journal of Geophysical Research: Oceans 113(C5).

https://doi.org/10.1029/2007JC004158

Ferguson, S.H., Stirling, I., and McLoughlin, P. 2005. Climate change and ringed seal (Phoca hispida) recruitment in western Hudson Bay. Marine Mammal Science 21(1):121 - 135. https://doi.org/10.1111/j.1748-7692.2005.tb01212.x

Folkow, L.P., and Blix, A.S. 1995. Distribution and diving behaviour of hooded seals. In: Blix, A.S., Walløe, L., and Ulltang, Ø., eds. Whales, seals, fish and man. Developments in Marine Biology 4:193-202. https://doi.org/10.1016/S0163-6995(06)80023-5

- 1999. Diving behaviour of hooded seals (Cystophora cristata) in the Greenland and Norwegian Seas. Polar Biology 22(1):61-74.

https://doi.org/10.1007/s003000050391

Folkow, L.P., Nordøy, E.S., and Blix, A.S. 2004. Distribution and diving behaviour of harp seals (Pagophilus groenlandicus) from the Greenland Sea stock. Polar Biology 27(5):281-298. https://doi.org/10.1007/s00300-004-0591-7

Freitas, C., Kovacs, K.M., Ims, R.A., Fedak, M.A., and Lydersen, C. 2008. Ringed seal post-moulting movement tactics and habitat selection. Oecologia 155(1):193-204. https://doi.org/10.1007/s00442-007-0894-9

Hammill, M.O. 1993. Seasonal movements of hooded seals tagged in the Gulf of St. Lawrence, Canada. Polar Biology 13(5):307-310. https://doi.org/10.1007/BF00238357

Hammill, M.O., Lydersen, C., Ryg, M., and Smith, T.G. 1991. Lactation in the ringed seal (Phoca hispida). Canadian Journal of Fisheries and Aquatic Sciences 48(12):2471 - 2476. https://doi.org/10.1139/f91-288

Hammill, M.O., Lesage, V., and Carter, P. 2005. What do harp seals eat? Comparing diet composition from different compartments of the digestive tract with diets estimated from stable-isotope ratios. Canadian Journal of Zoology 83(10):1365 - 1372. https://doi.org/10.1139/z05-123

Haug, T., Tormod Nilssen, K., Lindblom, L., and Lindstrøm, U. 2007. Diets of hooded seals (Cystophora cristata) in coastal waters and drift ice waters along the east coast of Greenland. Marine Biology Research 3(3):123 - 133. https://doi.org/10.1080/17451000701358531

Jakobsson, M., Mayer, L., Coakley, B., Dowdeswell, J.A., Forbes, S., Fridman, B., Hodnesdal, H., et al. 2012. The international bathymetric chart of the Arctic Ocean (IBCAO), version 3.0. Geophysical Research Letters 39(12), L12609. https://oi.org/10.1029/2012GL052219

Jefferson, T.A., Webber, M.A., and Pitman, R.L. 2015. Marine mammals of the world: A comprehensive guide to their identification, $2^{\text {nd }}$ ed. London: Elsevier. 
Johannessen, O.M., Babiker, M., and Miles, M.W. 2011. Petermann Glacier, North Greenland: Massive calving in 2010 and the past half century. The Cryosphere Discuss 5(1):169-181. https://doi.org/10.5194/tcd-5-169-2011

Johnson, H.L., Münchow, A., Falkner, K.K., and Melling, H. 2011. Ocean circulation and properties in Petermann Fjord, Greenland. Journal of Geophysical Research: Oceans 116(1), C01003. https://doi.org/10.1029/2010JC006519

Joughin, I., Abdalati, W., and Fahnestock, M. 2004. Large fluctuations in speed on Greenland's Jakobshavn Isbrae glacier. Nature 432(7017):608-610. https://doi.org/10.1038/nature03130

Kapel, F.O. 1995. Feeding ecology of harp and hooded seals in the Davis Strait - Baffin Bay region. In: Blix, A.S., Walløe, L., and Ulltang, Ø., eds. Whales, seals, fish and man. Developments in Marine Biology 4:287-304.

https://doi.org/10.1016/S0163-6995(06)80031-4

Kovacs, K.M., and Lydersen, C. 2008. Climate change impacts on seals and whales in the North Atlantic Arctic and adjacent shelf seas. Science Progress 91(2):117-150. https://doi.org/10.3184/003685008X324010

Krafft, B.A., Kovacs, K.M., Frie, A.K., Haug, T., and Lydersen, C. 2006. Growth and population parameters of ringed seals ( $P$ usa hispida) from Svalbard, Norway, 2002-2004. ICES Journal of Marine Science 63(6):1136-1144.

https://doi.org/10.1016/j.icesjms.2006.04.001

Laidre, K.L., Stirling, I., Lowry, L.F., Wiig, Ø., Heide-Jørgensen, M.P., and Ferguson, S.H. 2008. Quantifying the sensitivity of Arctic marine mammals to climate-induced habitat change. Ecological Applications 18(sp2):S97-S125. https://doi.org/10.1890/06-0546.1

Laidre, K.L., Stern, H., Kovacs, K.M., Lowry, L., Moore, S.E., Regehr, E.V., Ferguson, S.H., et al. 2015. Arctic marine mammal population status, sea ice habitat loss, and conservation recommendations for the 21 st century. Conservation Biology 29(3):724-737. https://doi.org/10.1111/cobi.12474

Lowry, L.F., Frost, K.J., and Burns, J.J. 1980. Feeding of bearded seals in the Bering and Chukchi Seas and trophic interaction with Pacific walruses. Arctic 33(2):330-342. https://doi.org/10.14430/arctic2566

Lydersen, C. 1998. Status and biology of ringed seals (Phoca hispida) in Svalbard. NAMMCO Scientific Publications $1: 46-62$. https://doi.org/10.7557/3.2980

Lydersen, C., Assmy, P., Falk-Petersen, S., Kohler, J., Kovacs, K.M., Reigstad, M., Steen, H., et al. 2014. The importance of tidewater glaciers for marine mammals and seabirds in Svalbard, Norway. Journal of Marine Systems 129:452-471. https://doi.org/10.1016/j.jmarsys.2013.09.006

Mouginot, J., Rignot, E., Scheuchl, B., Fenty, I., Khazendar, A., Morlighem, M., Buzzi, A., and Paden, J. 2015. Fast retreat of Zachariæ Isstrøm, northeast Greenland: Science 350(6266):1357-1361.

https://doi.org/10.1126/science.aac7111
Münchow, A., Padman, L., and Fricker, H.A. 2014. Interannual changes of the floating ice shelf of Petermann Gletscher, North Greenland, from 2000 to 2012. Journal of Glaciology 60(221):489-499.

https://doi.org/10.3189/2014JoG13J135

Nick, F.M., Luckman, A., Vieli, A., Van der Veen, C.J., Van As, D., Van de Wal, R.S.W., Pattyn, F., Hubbard, A.L., and Floricioiu, D. 2012. The response of Petermann Glacier, Greenland, to large calving events, and its future stability in the context of atmospheric and oceanic warming. Journal of Glaciology 58(208):229-239. https://doi.org/10.3189/2012JoG11J242

Pelto, M.S., Hughes, T.J., and Brecher, H.H. 1989. Equilibrium state of Jakobshavns Ibra, West Greenland. Annals of Glaciology 12:127-131. https://doi.org/10.1017/S0260305500007084

Reeves, R.R. 1998. Distribution, abundance and biology of ringed seals (Phoca hispida): An overview. NAMMCO Scientific Publications 1:9-45.

Rignot, E., and Kanagaratnam, P. 2006. Changes in the velocity structure of the Greenland ice sheet. Science 311(5763):986-990. https://doi.org/10.1126/science.1121381

Ryg, M., Smith, T.G., and Øritsland, N.A. 1990. Seasonal changes in body mass and body composition of ringed seals (Phoca hispida) on Svalbard. Canadian Journal of Zoology 68(3):470-475.

https://doi.org/10.1139/z90-069

Siegstad, H., Neve, P.B., Heide-Jørgensen, M.P., and Härkönen, T. 1998. Diet of the ringed seal (Phoca hispida) in Greenland. NAMMCO Scientific Publications 1:229-241. https://doi.org/10.7557/3.2991

Smith, T.G., and Stirling, I. 1975. The breeding habitat of the ringed seal (Phoca hispida). The birth lair and associated structures. Canadian Journal of Zoology 53(9):1297-1305. https://doi.org/10.1139/z75-155

Stensland, E., Angerbjörn, A., and Berggren, P. 2003. Mixed species groups in mammals. Mammal Review 33(34):205-223.

https://doi.org/10.1046/j.1365-2907.2003.00022.x

Stirling, I. 2005. Reproductive rates of ringed seals and survival of pups in northwestern Hudson Bay, Canada, 1991-2000. Polar Biology 28(5):381 - 387. https://doi.org/10.1007/s00300-004-0700-7

Teilmann, J., Born, E.W., and Acquarone, M. 1999. Behaviour of ringed seals tagged with satellite transmitters in the North Water polynya during fast-ice formation. Canadian Journal of Zoology 77(12):1934-1946. https://doi.org/10.1139/z99-163

Tynan, C.T., and DeMaster, D.P. 1997. Observations and predictions of Arctic climatic change: Potential effects on marine mammals. Arctic 50(4):308-322. https://doi.org/10.14430/arctic1113

Vincent, W.F., Gibson, J.A.E., and Jeffries, M.O. 2001. Ice-shelf collapse, climate change, and habitat loss in the Canadian High Arctic. Polar Record 37(201):133 - 142. https://doi.org/10.1017/S0032247400026954 
Walsh, J.E., 2008. Climate of the Arctic marine environment. Ecological Applications 18(sp2):S3-S22.

https://doi.org/10.1890/06-0503.1
Woodgate, R.A., Aagaard, K., Muench, R.D., Gunn, J., Björk, G., Rudels, B., Roach, A.T., and Schauer, U. 2001. The Arctic Ocean boundary current along the Eurasian slope and the adjacent Lomonosov Ridge: Water mass properties, transports and transformations from moored instruments. Deep Sea Research Part I: Oceanographic Research Papers 48(8):1757-1792. https://doi.org/10.1016/S0967-0637(00)00091-1 